\title{
Cyclic AMP phosphodiesterase activity in Fasciola bepatica (L.) homogenates (*)
}

\author{
par T. SIMONIC, P. SARTORELLI et A. LOCATELLI \\ Istituto di Parassitologia, Facoltà di Medicina Veterinaria dell'Università degli Studi \\ di Milano, Via Celoria $n^{\circ} 10$, Milano, Italia
}

\section{Summary.}

The authors have studied the behaviour of cyclic 3',5'-AMP phosphodiesterase in the 2,000 g supernatant of the Fasciola hepatica homogenate, under basal conditions and after addition of various substances. Dopamine remarkably inhibits the enzyme activity, imidazole causes a strong activation, while serotonin, theophylline, $\mathrm{PGE}_{1}$, and $\mathrm{PGF}_{2 \alpha}$ appear to be ineffective.

\section{Résumé.}

Activité de l'AMP cyclique phosphodiestérase dans les homogénats de Fasciola hepatica (L.).

On a considéré l'activité in vitro de la $3^{\prime}, 5^{\prime}$-AMP cyclique phosphodiesterase dans les surnageants obtenus par centrifugation à $2000 \mathrm{~g}$ des homogénats de Fasciola hepatica bruts ou après addition de différentes substances. La dopamine provoque une inhibition marquée de cette activité enzymatique, l'imidazole cause une forte activation, tandis que la sérotonine, la théophylline, la $\mathrm{PGE}_{1}$ et la $\mathrm{PGF}_{2 a}$ ne montrent aucun effet appréciable.

\section{Introduction}

The Trematode parasite Fasciola hepatica was the first non mammalian organism in which adenyl cyclase was found (Mansour et al., 1960) and successively the role of 3',5'-cyclic AMP was investigated.

(*) Supported by C.N.R. grant $\mathrm{n}^{\circ}$ CT73.00623.04. 
Mansour et al. (1960) and Mansour and Stone (1970) have demonstrated that serotonin affects the carbohydrate metabolism, increasing glycolysis and glycogen break-down, and that these effects are mediated by cyclic AMP. Moreover, this amine appears to be able to stimulate motility of the liver fluke (Mansour, 1957 ; Beretta and Locatelli, 1968 ; Luxardo et al., 1969), so that it was suggested in this case too cyclic AMP involvement (Robison et al., 1971), but this has yet to be experimentally estabilished.

Although the potentiation of serotonin action on carbohydrate metabolism, displayed by caffeine, was attributed to the inhibition of PDE (cyclic 3',5'-AMP phosphodiesterase) causing an increase of the intracellular concentration of cyclic AMP (Stone and Mansour, 1967), we failed to find detailed information, in the current literature, on the behaviour of this enzyme, with the exception of one issue in which no exhaustive details are reported (Mansour et al., 1960).

In order to characterize at least some features of PDE in Fasciola hepatica homogenates, we have assayed, on this enzyme activity, the possible effects of some substances (serotonin, theophylline, imidazole, $\mathrm{PGE}_{1}, \mathrm{PGF}_{2 \alpha}$ and dopamine) having known relationship with cyclic AMP metabolism.

The choise of dopamine has been suggested on one side because it was recently reported that this drug is, among the amines considered by the authors (serotonin, norepinephrine and dopamine), the only one recognized in Fasciola hepatica (Chou et al., 1972), and on the other because its ability to inhibit PDE has already been reported for other organisms (Goren and Rosen, 1972 ; Sheppard et al., 1972). The availability of dopamine and the lack of norepinephrine (Chou et al., 1972) suggest that the former may play a role different from norepinephrine precursor. Regarding this point it was already noticed that in insects dopamine acts like precursor of $\mathrm{N}$-acetyl-dopamine, which is involved in cuticle hardening (Cottrell and Laverack, 1968), a pattern in which phenol oxidase is concerned. Since in Fasciola hepatica the same enzyme seems to play a similar role (hardening of the egg shell) (Smyth, 1954 ; Smyth and Clegg, 1959) and shows a particular affinity to dopamine as substrate (Mansour, 1958), this field of investigation appears of remarkable interest.

\section{Materials and methods}

Liver flukes were extracted from cattle bile ducts, incubated in glucosate-antibiotate Tyrode solution added with horse serum $10 \%$ at $37^{\circ} \mathrm{C}$ during 12 hours. After washing in $\mathrm{NaCl} 0.9 \%$, the living parasites with normal motility were employed for PDE activity assay.

The flukes were suspended in $0.25 \mathrm{M}$ sucrose $1: 5(\mathrm{w} / \mathrm{v})$ and homogenized in an all glass homogenizer (Potter) motor driven, kept into ice bath.

Aliquots of the homogenate were centrifuged at 2,000 $\mathrm{g}$ and at 17,000 g/20 minutes at $0^{\circ} \mathrm{C}$. PDE assays were carried out on « in toto » homogenate, on the sediments. and on the supernatants obtained on both centrifugations. 
Since 2,000 g supernatant exhibited the highest PDE activity, the enzyme assay was then performed only on this fraction according to Butcher and Sutherland method (1962), modified by McNeill et al. (1972).

The incubation mixture, in a final volume of $\mathrm{ml} 0.5$, contained: $\mathrm{ml} 0.35$ of $0.05 \mathrm{M}$ Tris $\mathrm{pH} 7.5-2.5 \mathrm{mM} \mathrm{MgCl}_{2} ; \mathrm{ml} 0.1$ of $20 \mathrm{mM}$ cyclic 3',5'-AMP and $\mathrm{ml} 0.05$ of Fasciola hepatica $2,000 \mathrm{~g}$ supernatant. The enzyme-buffer mixture was preequilibrated in a Dubnoff bath at $37^{\circ} \mathrm{C}$ for 5 minutes; the reaction was then started by adding cyclic AMP. The reaction was stopped at different times $(10,20$ and 30 minutes) by immersion in a boiling water bath for 4 minutes. For each sample there was a blank, containing the only enzyme-buffer mixture boiled before starting the reaction.

At the end of the reaction, each tube was added with $\mathrm{ml} 0.1$ of 5 '-nucleotidase solution $(0.5 \mathrm{mg} / \mathrm{ml}$; grade II, Sigma Chem. Co.) in $0.6 \mathrm{M}$ Tris buffer $\mathrm{pH} 9.5$. After incubation at $37^{\circ} \mathrm{C}$ for 30 minutes, the reaction was stopped as above described. Inorganic phosphate was measured by the method of Chen et al. (1956), modified with regard to the TCA concentration (TCA $20 \%$ mixed with the same volume of the sample).

Protein contents were determined in the 2,000 g supernatant of Fasciola hepatica homogenate according to Lowry et al. (1951). PDE activity was expressed as $\mu \mathrm{g}$ phosphate/mg protein.

The following substances at the final under reported concentrations were tested on PDE activity:

1) Serotonin (5-HT creatinine sulfate, Sigma Chem. Co.), $10^{-4} \mathrm{M}$;

2) Theophylline $(\mathrm{BDH}), 10^{-2} \mathrm{M}$;

3) Imidazole (Merck), $10^{-2} \mathrm{M}$;

4) $\mathrm{PGE}_{1}$ and $\mathrm{PGF}_{2 \alpha}$ (Upjohn Co.), $20 \mathrm{ng} / \mathrm{ml}$;

5) Dopamine (3-hydroxy-tyramine, BDH), $10^{-2} \mathrm{M}$.

All these substances were tested, in order to evaluate their possible effects on 5 '-nucleotidase activity. None of the substances was able to affect this enzyme activity.

\section{Results}

The experiments carried out lead to the following findings :

a) the enzyme activity appears unaffected by serotonin $10^{-4} \mathrm{M}$ (table $I$ );

b) theophylline $10^{-2} \mathrm{M}$ slightly decreases the reaction rate during the whole time of incubation ( 30 minutes), without being statistically significant the difference from the controls (table II and fig. 1); 
c) imidazole $10^{-2} \mathrm{M}$ brings about a remarkable increase of PDE activity, which exceeds the mean values of the correspondent controls at 10,20 and 30 minutes in a highly significant way (table II and fig. 1);

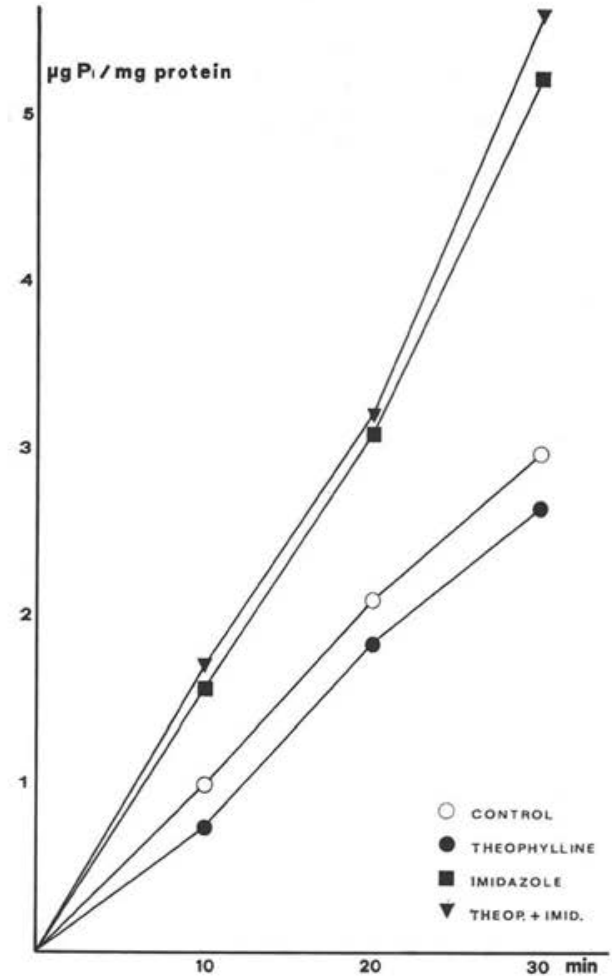

FIG. 1. - Cyclic AMP phosphodiesterase activity in $2,000 \mathrm{~g}$ supernatant of the liver fluke homogenate untreated and after addition of theophylline, imidazole and theophylline + imidazole.

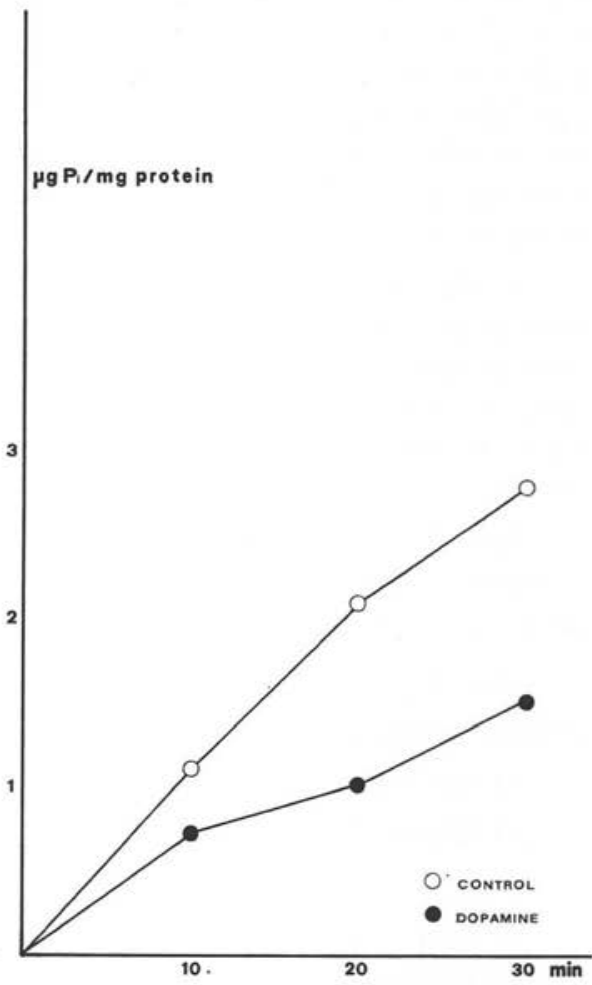

FIG. 2. - Cyclic AMP phosphodiesterase activity in $2,000 \mathrm{~g}$ supernatant of the liver fluke homogenate untreated and after addition of dopamine.

d) when theophylline and imidazole are added at the same time to the reaction mixture, the effect is qualitatively the same as seen for imidazole alone (table II and fig. 1). At present our trials do not allow to admit a potentiation of imidazole effect by theophylline, but it may be possible ;

e) both $\mathrm{PGE}_{1}$ and $\mathrm{PGF}_{2 \alpha}$ fail in affecting anyhow the PDE activity (table I) ;

$f$ dopamine causes a progressive inhibition, that results very marked at the 30 th minute of reaction (table $I$ and fig. 2). 
TABLE I. - PDE activity in Fasciola hepatica homogenates. Mean values are expressed in $\mathrm{ug} \mathrm{P} / \mathrm{mg}$ protein.

\begin{tabular}{|c|c|c|c|c|}
\hline \multirow{2}{*}{ Drugs } & \multirow{2}{*}{$\begin{array}{c}\text { No. of } \\
\text { observations }\end{array}$} & \multicolumn{3}{|c|}{ Mean values $( \pm$ S.E. $)$ at } \\
\hline & & $10 \mathrm{~min}$. & $20 \mathrm{~min}$. & $30 \mathrm{~min}$. \\
\hline None $\ldots \ldots \ldots \ldots \ldots \ldots \ldots$ & 28 & $\begin{array}{r}1.11 \\
\pm 0.11\end{array}$ & $\begin{array}{r}2.09 \\
\pm 0.18\end{array}$ & $\begin{array}{r}2.79 \\
\pm 0.18\end{array}$ \\
\hline Serotonin $(10-4 \mathrm{M}) \ldots \ldots \ldots$ & 5 & $\begin{array}{r}1.06 \\
\pm 0.17 \\
\end{array}$ & $\begin{array}{r}2.41 \\
\pm 0.39\end{array}$ & $\begin{array}{r}3.29 \\
\pm 0.35\end{array}$ \\
\hline $\mathrm{PGE}_{1}(20 \mathrm{ng} / \mathrm{ml}) \ldots \ldots \ldots \ldots$ & 5 & $\begin{array}{r}1.02 \\
\pm 0.36\end{array}$ & $\begin{array}{r}2.11 \\
\pm 0.50\end{array}$ & $\begin{array}{r}3.09 \\
\pm 0.77\end{array}$ \\
\hline $\mathrm{PGF}_{, \alpha}(20 \mathrm{ng} / \mathrm{ml}) \ldots \ldots \ldots \ldots$ & 5 & $\begin{array}{r}0.90 \\
\pm 0.17\end{array}$ & $\begin{array}{r}1.62 \\
\pm 0.41\end{array}$ & $\begin{array}{r}2.30 \\
\pm 0.38\end{array}$ \\
\hline Dopamine $\left(10^{-2} \mathrm{M}\right) \ldots \ldots \ldots$ & 5 & $\begin{array}{r}0.73 \\
\pm 0.14\end{array}$ & $\begin{aligned} & 1.01 * \\
\pm & 0.31\end{aligned}$ & $\begin{aligned} & 1.53 \text { ** } \\
\pm & 0.34\end{aligned}$ \\
\hline
\end{tabular}

TABLE II. - PDE activity in Fasciola hepatica homogenates. Mean values are expressed in $\mu \mathrm{g} \mathrm{P} / \mathrm{mg}$ protein.

\begin{tabular}{|c|c|c|c|c|}
\hline \multirow{2}{*}{ Drugs } & \multirow{2}{*}{$\begin{array}{l}\text { No. of } \\
\text { observations }\end{array}$} & \multicolumn{3}{|c|}{ Mean values ( \pm S.E.) at } \\
\hline & & $10 \mathrm{~min}$. & $20 \mathrm{~min}$. & $30 \mathrm{~min}$. \\
\hline None $\ldots \ldots \ldots \ldots \ldots \ldots \ldots$ & 10 & $\begin{array}{r}1.00 \\
\pm 0.07\end{array}$ & $\begin{array}{r}2.11 \\
\pm 0.16\end{array}$ & $\begin{array}{r}2.98 \\
+0.29\end{array}$ \\
\hline Theophylline $(10-2 \mathrm{M}) \ldots \ldots$ & 7 & $\begin{array}{r}0.74 \\
\pm 0.16\end{array}$ & $\begin{array}{r}1.84 \\
\pm 0.26\end{array}$ & $\begin{array}{r}2.65 \\
\pm 0.18\end{array}$ \\
\hline Imidazole $(10-2 \mathrm{M}) \ldots \ldots \ldots$ & 3 & $\begin{aligned} & 1.57 \text { ** } \\
\pm & 0.12\end{aligned}$ & $\begin{aligned} & 3.09 * * \\
\pm & 0.13\end{aligned}$ & $\begin{aligned} & 5.21 * * \\
\pm & 0.60\end{aligned}$ \\
\hline $\begin{array}{l}\text { Theophylline }(10-2 \mathrm{M})+\text { Imida- } \\
\text { zole }(10-2 \mathrm{M}) \ldots \ldots \ldots \ldots \ldots \ldots\end{array}$ & 3 & $\begin{array}{l}1.71 \text { ** } \\
\pm 0.10\end{array}$ & $\begin{aligned} & 3.21 * * \\
\pm & 0.33\end{aligned}$ & $\begin{aligned} & 5.58^{* *} \\
\pm & 0.23\end{aligned}$ \\
\hline
\end{tabular}

\section{Discussion}

Our findings show that in Fasciola hepatica the PDE activity is distributed between the soluble and particulate fractions; it appears to be rather high, as was reported previously for adenyl cyclase activity (Mansour et al., 1960 ; Dragoni et al., 1972).

The in vitro behaviour of PDE, after serotonin, imidazole and dopamine addition, basically agrees with what already seen by others (Mansour, 1960; Butcher and 
Sutherland, 1962 ; Honda and Imamura, 1968 ; Goren and Rosen, 1972 ; Sheppard et al., 1972).

The prostaglandins employed $\left(\mathrm{PGE}_{1}\right.$ and $\mathrm{PGF}_{2 \alpha}$ ) are ineffective on enzyme activity of this parasite; we did not find any report about this in the current literature, except for a possible action of $\mathrm{PGE}_{1}$ upon the PDE synthesis in fibroblasts (Appleman et al., 1973).

The relative failure of enzyme inhibition by theophylline is however the main characteristic emerged from our investigations. Such a feature makes Fasciola hepatica PDE more similar to the enzyme of certain bacteria (Pastan and Perlman, 1970) than to the mammalian one (Butcher and Sutherland, 1962). This latter finding is rather surprising since an other metyl-xantine (caffeine) was by some authors (Mansour et al., 1960) reported to largely prevent inactivation of cyclic AMP : unfortunately such an observation does not appear supplied by an adequate evidence. The discrepancy between the above mentioned results could depend upon the measuring, for the most part, different types of PDE even if it does not seem to be the case, because the Fasciola hepatica preparations were obtained by the same way. Now it is well established that several PDE isoenzymes do exist in the same tissue too (Monn et al., 1972), and it can even happen, as pointed out by Andersson (1972), that the same substance can either activate or inhibit PDE activity, when assayed on different cell fractions of the same tissue.

\section{Bibliography}

Appleman (M. M.), Thompson (W. J.) et Russell (T. R.), 1973. - Cyclic Nucleotide Phosphodiesterases. In: Adv. in Cyclic Nucleotide Research, ed. Greengard P. e. Robison G. A., vol. III, 65-98, Raven Press, Publ., N.Y.

Andersson (R. G.G.), 1972. - Cyclic AMP and calcium ions in mechanical and metabolic responses of smooth muscles; influence of some hormones and drugs. Acta Physiol. Scand., suppl., 382.

Beretta (C.) et Locatelli (A.), 1968. - Inhibitory activity of $8 \beta$-carbobenzyloxyaminomethyl-1,6-dimethyl-10 $\alpha$-ergoline towards stimulant effects by 5-hydroxytryptamine and amphetamine on liver fluke, Fasciola hepatica, in vitro. J. Pharm. Pharmac., $20,744-745$.

Butcher (R. W.) et Sutherland (E. W.), 1962. - Adenosine 3',5'-Phosphate in Biological Materials. 1. Purification and properties of cyclic $3^{\prime}, 5^{\prime}$-nucleotide phosphodiesterase and use of this enzyme to characterize adenosine $3^{\prime}, 5^{\prime}$-phosphate in human urine. J. Biol. Chem., 237, 1244-1250.

Chen (P.S.), Toribara (T. Y.) et Warner (H.), 1956. - Microdetermination of Phosphorus. Anal. Chem., 28, 1756-1758. 
Chou (T. T.), Bennett (J.) et Bueding (E.), 1972. - Occurrence and concentrations of biogenic amines in trematodes. J. Parasit., 58, 1098-1102.

Cottrell (G. A.) et Laverack (M. S.), 1968. - Invertebrate pharmacology. Ann. Rev. Pharmacol., 8, 273-298.

Dragoni (G.), Locatelli (A.) et Simonic (T.), 1972. - Livelli di attività adenilciclasica nel trematode Fasciola hepatica. Parassitologia, 14, 309-310.

Goren (E. N.) et Rosen (O. M.), 1972. - Inhibition of a Cyclic Nucleotide Phosphodiesterase from Beef Heart by Catecholamines and Related Compounds. Mol. Pharmacol., 8, 380-384.

Honda (F.) et Imamura (H.), 1968. - Inhibition of cyolic 3',5'-nucleotide phosphodiesterase by phenothiazine and reserpine derivates. Biochim. Biophys. Acta, 161, 267-269.

Lowry (O. N.), Rosebrough (N. J.), FarR (A. L.) et Randall (R.), 1951. - Protein measurement with the Folin phenol reagent. J. Biol. Chem., 193, 265.

Luxardo (M.), Beretta (C.) et Locatelli (A.), 1969. - Contributo alla conoscenza dei meccanismi di mediazione neuro-muscolare nella motilità di $F$. hepatica in vitro. Veterinaria, 18, 188-196.

Mansour (T. E.), 1957. - The effect of lysergic acid diethylamide, 5-hydroxytryptamine, and related compounds on the liver fluke, Fasciola hepatica. Brit. J. Pharmacol., 12 , 406-409.

Mansour (T.E.), 1958. - Effect of serotonin on phenol oxidase from the liver fluke Fasciola hepatica and from other sources. Biochim. Biophys. Acta, 30, 492-500.

Mansour (T. E.), et STONE (D. B.), 1970. - Biochemical effects of lysergic acid diethylamide on the liver fluke Fasciola hepatica. Biochem. Pharmacol., 19, 1137-1146.

Mansour (T. E.), Sutherland (E. W.), Rall (T. W.) et Bueding (E.), 1960. - The effect of serotonin (5-hydroxytryptamine) on the formation of adenosine 3',5'-phosphate by tissue particles from the liver fluke, Fasciola hepatica. J. Biol. Chem., $235,466-470$.

McNeill (J. H.), Lee (C.) et Muschex (L. D.), 1972. - The effect of phentolamine and other drugs on Rat brain phosphodiesterase. Can. J. Physiol. Pharmacol., 50, 840-844.

Monn (E.), Desautel (M.) et Christiansen (R. O.), 1972. - Highly specific testicular adenosine 3',5'-monophosphate phosphodiesterase associated with sexual maturation. Endocrinology, 91, 716-720.

Pastan (I.) et Perlman (R.), 1970. - Cyclic adenosine monophosphate in Bacteria. Science, 169, 339-344.

Robison (G. A.), Butcher (R. W.) et Sutherland (E. W.), 1971. - Cyclic AMP, 338-399. Academic Press, Publ., New York and London.

Sheppard (H.), Wiggan (G.) et Tsien (W. H.), 1972. - Structure-activity relationships for inhibitors of phosphodiesterase from erythrocytes and other tissues. In : «Adv. in cyclic Nucleotide Research», ed. P. Greengard, R. Paoletti e G. A. Robison, vol. I, 103-112. Raven Press, Publ., N.-Y. 
SMYTH (J. D.), 1954. - A technique for the histochemical demonstration of polyphenol oxidase and its application to egg-shell formation in helminths and byssus formation in Mytilus. Quart. J. micr. Sci., 95, 139-152.

SMYth (J. D.) et Clegg (J.A.), 1959. - Egg-shell formation in trematodes and cestodes. Exp. Paras., 8, 286-323.

Stone (D. B.) et Mansour (T. E.), 1967. - Phosphofructokinase from the Liver Fluke Fasciola hepatica. I. Activation by adenosine 3',5'-phosphate and by serotonin. Mol. Pharmacol., 3, 161-176. 